\title{
COMMUNICATION STRATEGY PRIVATE COLLEGE IN INCREASE BRAND EQUITY
}

\author{
Agus Kristian $^{1}$ \\ University of Muhammadiyah Tangerang \\ aguschristian1589@gmail.com
}

Kristian, A. (2022). Communication Strategy Private College In Increase Brand Equity. Journal of English Language and literature. Journal of English Language and literature, 7(1), 27-34. doi: 10.37110/jell.v7i1.140

Received: 11-01-2022

Accepted: 22-01-2022

Published:03-03-2022

\begin{abstract}
This study examines brand and communication strategies undertaken by Muhammadiyah University of Tangerang in building brand equity. The purpose of research to know and evaluate brand and communication strategy in building brand equity of Muhammadiyah University of Tangerang dissemination of competition of private universities in increasing number of new students. Theoretical basis of research is the theory of brand equity. The paradigm in this research is constructivist paradigm, using qualitative approach and through case study method to look for its specificity. Primary data were obtained from key informants through interviews and observation. While secondary data obtained through document studies. Data were analyzed qualitatively using brand equity elements as well as withdrawal of conclusions or verifications. To check the validity of data is done by tringulasi sources and methods and discuss with colleagues. The results showed that: First, the factor of formation of brand equity of Muhammadiyah University of Tangerang include: (1). 1) Institutional and Study Accreditation, 2) Achievements, 3) Campaign Superior Activities, 4) Premium Cost, 5) Shif Class, and 6) Relationship with Alumni.
\end{abstract}

Keywords: Brand Strategy, Brand Equity

\section{INTRODUCTION}

Higher education as the highest level of education is a center for the development of knowledge, a center for research and community service in accordance with the functions of the Tri Dharma. Higher Education can support the development of the quality of Indonesian human resources. In Indonesia itself, there are many universities, both private and public, which are widely spread from Sabang to Merauke. The increasing number of universities in Indonesia creates a phenomenon of competition both between State Universities (PTN) and Private Universities (PTS) or PTN with other PTN and PTS with other PTS.

Rapid and dramatic developments and environmental changes, including changes in consumer tastes, technological advances and socioeconomic changes, have played a role in influencing the higher education sector, resulting in fierce business competition in the education industry. According to Siagian, Sondang. (1995:54). Developments and changes occur across 
geographies. Popularly, this development is known as globalization. Such conditions require every private university to be able to explore and develop sources of excellence in order to be able to compete with state universities and with other private universities.

In conducting competition between private universities in increasing student input, it is not enough to use a brand strategy but must also be supported by a communication strategy because communication is an interaction activity between humans, where communication touches all aspects of life that are very important, so communication is like the lifeblood of life. human social life, so some communication experts, many of whom give limits to what is meant by communication, according to their point of view. Raymond S. Ross, in Mulyana, communication is a process of sorting, selecting and sending symbols in such a way as to help listeners generate meanings or responses from their minds that are similar to those intended by the communicator.

The occurrence of communication is as a consequence of social relations, the community consists of at least two people who are interconnected with each other, from these relationships lead to social interactions. The occurrence of social interaction due to communication interactions. The term communication comes from the Latin, namely communis, which means "the same". Communico, communicatio or communicare means to make the same (make to common). So, communication can occur if there is a common understanding between the sender of the message and the recipient of the message. In a series of communication activities that are used strategically to achieve communication goals, there are stages of Strategy \& Tactics, where to communicate a systematic strategy, channels are needed to communicate to the target audience.

Smith (1995:67) mentions 11 (eleven) promotional tools (where promotion is one element of the "7 Ps" marketing mix - (product, price, place, promotion, people, physical evidence, process) that can be used, but more related to branding activities are Advertising, Publicity (and PR), Sponsorship, Exhibition, Packaging, Point of sale and Merchandising, Multimedia \& Internet, and Word of Mouth. Meanwhile, Kottler \& Fox mentions 3 (three) communication tools related to university branding activities high, namely: Public Relations, Advertising and Word of Mouth.

Strategic Communication is a series of communication activities that are used strategically to achieve communication goals and are carried out through systematic stages, and end with an evaluation to measure its success. The definition of strategic communication is nothing more than a rigorous process of planning and executing a campaign to address a particular issue that will ultimately result in a cohesive communication plan. This process produces a roadmap where communication strategies are carefully crafted, goals are developed, targets are strictly defined, research and information needs are identified, and optimally combines marketing and strategic communications activities and tactics created in a cost-effective manner to deliver results. which are desired.

\section{METHOD}

In this study, the researcher wanted to know about the Brand Strategy and Communication of Private Universities in Building Brand Equity. The research approach used by the researcher is a qualitative approach. According to Sugiono (2009:10). The qualitative approach views the object as something dynamic, the result of the construction of thoughts and interpretations of the observed phenomena, and intact because every aspect of the object has a unity that cannot be separated. Qualitative research seeks to construct reality and understand its meaning. Thus, qualitative research is very concerned with processes, events and authenticity. In qualitative research, the presence of the researcher's value is 
explicit in limited situations, involving relatively few subjects.

Qualitative researchers are usually involved in interacting with the reality they are studying. The use of deductive logic is very important in this paradigm, where categorization is born from the researcher's encounter with informants in the field or the data found. So that qualitative researchers are characterized by information in the form of contextual bonds that will lead to patterns or theories that will explain social phenomena. The explanation above regarding the qualitative research approach, the researcher concludes that the relation to the main problem of the research is in the form of data that will be studied further regarding the Brand Strategy and Communication of Private Universities in Building Brand Equity.

According to Sulaeman, and Goziyah. (2019:45). The research method is a scientific way to obtain data with the aim of certain uses. The data obtained through research is empirical data that has certain criteria, namely valid. Each research has a specific purpose and use. The research method used to answer the Brand Strategy and Communication of Private Universities in Building Brand Equity is the case study method. A case study or case study is part of a qualitative method that wants to explore a particular case in greater depth by involving the collection of various sources of information. Creswell (2010:20). defines a case study as an exploration of bounded systems or cases.

The approach used is a qualitative approach because it wants to see the context of the problem as a whole, with a research focus on the process and on the results. According to Denzin and Lincoln, qualitative research is research that uses a natural setting with the intention of interpreting the phenomena that occur and is carried out by involving various existing methods. The methods commonly used are observation interviews and document utilization. The collection of information in the case study in this study was conducted at the Muhammadiyah University of Tangerang. With this method, researchers are expected to capture the complexity of the selected cases. This method is used because the selected cases are so unique and important that they are useful for readers and the general public.

\section{FINDING AND DISCUSSION}

Muhammadiyah University of Tangerang as one of the private universities is a business charity of the Muhammadiyah organization which has an important role in improving the intelligence of the nation's children in general and the people of Tangerang City in particular. The role of universities in developing the potential of human resources is a barometer of success in educating the nation's generation, this success can be done by the availability of quality human resources based on the chess dharma of universities in its implementation which refers to Government Regulation no. 66 of 2010 concerning the management and implementation of education and qoidah of Muhammadiyah higher education institutions, namely: 1). Education 2). Research 3). Community Service and, 4) Al-Islam and Muhammadiyah.

In order to realize the above, it is necessary to formulate a brand and communication strategy that is able to create brand equity and be able to create value for the University of Muhammadiyah Tangerang so that it remains a destination for the community to choose Muhammadiyah University of Tangerang in studying diploma, undergraduate and postgraduate education in student admissions. between private universities. According to David Aaker in Durianto's book brand equity in creating value for companies or consumers on the basis of five categories of elements, the five elements are brand awareness, brand associations, perceived quality, brand loyalty brand loyalty) and other brand-related assets.

Interviews were conducted using purposive techniques to various informants conducted at the Muhammadiyah University of Tangerang. Data that were not revealed through interviews, are 
supplemented with data from direct participatory observations conducted from the beginning of November to the end of November 2017. To strengthen the substance of the data from interviews and observations, a search was carried out on existing documents and archives. All data from this research are described based on the focus of the research questions as follows:

\section{Brand Awareness}

Researchers conducted interview and documentation techniques to obtain data from brand awareness elements related to the strategy of Universitas Muhammadiyah Tangerang to create the strength of the existence of Universitas Muhammadiyah Tangerang in the minds of the public. society consisting of top of mind, brand recall, and unware of brand dimensions. So that the researchers looked to find out what strategies were carried out by the Muhammadiyah University of Tangerang regarding brand awareness along with excerpts from an interview with the Head of the New Student Admissions Team at the University of Muhammadiyah Tangerang, Mr. Dr. H. Desri Arwen, M.Pd :

"The effort of Universitas Muhammadiyah Tangerang to always be the first choice for people to study is that we always improve the value of accreditation, both institutional accreditation and faculty accreditation, currently our institutional accreditation has been accredited "B" by BAN-PT and almost $90 \%$ of our study programs have been accredited "B" $B A N-P T$, because after all accreditation is one of the main choices besides the choice of location, cost and majors chosen by prospective students. (Interview dated, 06 November 2017).

From the excerpt of an interview with the head of the new student admissions team at Muhammadiyah University of Tangerang who has explained the strategy of the University of Muhammadiyah Tangerang in the effort of the University of Muhammadiyah Tangerang to create brand awareness in the community. The researcher concludes that the main thing in creating brand awareness by Muhammadiyah University is to maintain the value of accreditation where accreditation is one of the selling points that can influence people's choices to study at Muhammadiyah University in Tangerang. In this case, according to the results of the documentation in the form of an accreditation certificate from the Muhammadiyah University of Tangerang with a value of $\mathrm{B}$ according to the decision letter number of the National Accreditation Board for Higher Education 195/SK/BAN-PT/Akred/PT/IV/2015 which is valid until April 10, 2020 as in the attachment.

\section{Brand Association}

In this study, five basic things are described related to the brand association that forms the brand image that makes the consumer's footing in purchasing decisions and loyalty to the brand. In practice, there are many possible associations and variations of band associations that can provide value for a brand, from the company's point of view as well as from the user's point of view, including helping the process of compiling information, differentiating, buying reasons, creating positive attitudes or feelings, and providing a basis for expansion.

Researchers conducted interview, documentation, and observation techniques to obtain data on the strategy of Universitas Muhammadiyah Tangerang in building brand equity through brand association elements which were divided into several parts. Dr. H. Desri Arwen, M.Pd in the following interview excerpts:

"Actually, many of our product attributes that are easily recognized by the public, starting from the logo, location, low cost and class shift, are all one unit that can be recognized by the public, but among the attributes that dominate easily recognized by the public is class. shift" (Interview, 10 November 2017). 
Excerpts from the interview with the head of the new student admissions team have explained the various attributes inherent in the Muhammadiyah University of Tangerang. Based on the observations of the researchers, the most dominant brand association associated with the University of Muhammadiyah Tangerang is the low tuition fee (relative price).

Brands play a very important role, one of which is to bridge consumer expectations when we promise something to consumers. The brand is the most valuable asset for the company, because the brand is one of the basic advantages to compete with other competitors. A brand is not just a name or symbol of a product, more than that a brand is the most valuable asset of a company to consistently provide maximum service to customers. So that customers will remember the brand as a quality product.

Universitas Muhammadiyah Tangerang tries to present an educational service with good quality but still offers affordable prices for the community. As expressed by Dr. H. Desri Arwen, M.Pd as follows:

"Universitas Muhammadiyah Tangerang has a noble goal in implementing this education service business to the community. We have many hopes that we have strived for these eight years in order to be able to serve students and prospective students maximally, as I stated earlier the first thing we do is maintain the accreditation of institutions and study programs because that is our quality identity, then we want to convince the public, especially the middle class and below they are able to fulfill postgraduate, undergraduate and diploma education at affordable costs and can be paid in installments with the hope that they will be able to change their degree of life" (Interview on November 16, 2017).

In an effort to build strong brand equity so that Universitas Muhammadiyah Tangerang is able to stick in the minds of the community. Universitas
Muhammadiyah Tangerang performs the following stages of communication:

\section{Customer Segmentation}

Determination of market segmentation is a very important thing that must be done because this affects the decision to choose what media to use in marketing. For the selection of market segmentation, Muhammadiyah University of Tangerang targets the lower middle class, namely people who have limited funds but want to continue their postgraduate, undergraduate and diploma studies, this is reflected in the large number of students studying at Muhammadiyah University of Tangerang who come from the north coast of Tangerang who incidentally are fishermen and fishermen. farmer. However, the University of Muhammadiyah Tangerang does not limit it if there are people from the upper classes to study at the University of Muhammadiyah Tangerang, we continue to provide the same services for both those from the lower middle class and the upper middle class. This was explained by Mr. Dr. H. Desri Arwen, M.Pd in the following interview excerpts:

"We pay special attention to promoting certain areas, such as the northern part of Tangerang Regency, starting from Tanjung Pasir, Kresek, Koja to Balaraja there. We carried out maximum promotions there such as installing banners at their schools, installing promotional stands at school events and providing scholarships to those who excel in the form of cutting tuition fees" (Interview on November 16, 2017).

After the determination of market segmentation has been agreed upon by the head of the new student admissions team of Universitas Muhammadiyah Tangerang, the PR team will carry out promotional tasks with the direction and instructions of the head of the new student admissions team.

\section{Customization}


Universitas Muhammadiyah Tangerang is a private university campus which is strategically located in the heart of Tangerang city, located in the Cikokol education complex in Tangerang and adjacent to the business district and mall. This location is a distinct advantage for Muhammadiyah University of Tangerang because it is easily accessible by students from various regions in Tangerang Raya. The head of the public relations department at the University of Muhammadiyah Tangerang, Mr. Drs Khoerudin, MM, said the same thing as follows:

"We have advantages and benefit from our very strategic location, a location that is easy to reach from anywhere by motorbike and car, ordinary roads or via toll roads. In addition, our location is very close to business locations, namely Tangcity and Tangcity Mall, so if there are students who want to go to the mall to watch movies and look for books, they don't have to bother riding motorbikes, they can walk" (Interview on November 20, 2017 ).

In addition to the location, the other most important factor in influencing the University of Muhammadiyah Tangerang is the impression of the quality of the services that are reflected in order to be able to survive and remain competitive with other private universities. Various dimensions of the impression of quality are very much displayed, including the quality of performance, the quality of facilities, the suitability of the physical appearance with what is offered to students through brochures and so on related to the impression of quality.

\section{Delight Targeted Customers}

As explained by previous informants, the concept of communication strategy carried out by the University of Muhammadiyah Tangerang is integrated marketing communication, which combines the concept of marketing with customer relations and service maintenance. Prospective new students become full attention in doing marketing. It will be easy for marketing if the company's image has been created because the image cannot be engineered but the image can be generated from the dissemination of information that is relevant to the actual situation.

To fulfill this, it is necessary to have a maximum product introduction effort, this is where the role of marketing communication is needed and very important, because through marketing communication the public can find out the products owned by Muhammadiyah University of Tangerang. Universitas Muhammadiyah Tangerang is well aware of the important role of marketing communication which is part of building brand equity. Therefore, the new student admissions department is fully responsible for marketing communication activities at the University of Muhammadiyah Tangerang to the maximum. As stated by Mr. Ofan Sofian the following:

"The new student admissions division always makes maximum efforts in conducting marketing communications to the community, we optimize all marketing facilities that we have, both in terms of human resources and other supporting facilities, brochures, banners, social media and websites. We always work on a target to be able to meet the needs of the number of students at Muhammadiyah Tangerang University every year, and Alhamdulillah, we always fulfill that" (Interview, 20 November 2017).

By carrying out optimal and targeted marketing communication activities, Universitas Muhammadiyah Tangerang hopes that the public will be more familiar with Universitas Muhammadiyah Tangerang with various qualities in it and eventually choose Universitas Muhammadiyah Tangerang to study.

The results of the research above are a field research process that has been carried out by researchers for a period of one month, namely November 2017 with the fulfillment of research administration requirements from universities, 
namely a research permit to the Muhammadiyah University of Tangerang to the approval of informants from the new student admissions team of Muhammadiyah University of Tangerang. This study uses a qualitative method with a constructivist approach about how the Brand Strategy and Communication of Private Universities in Building Brand Equity is a case study at the Muhammadiyah University of Tangerang.

\section{CONCLUSION}

First, the factors for establishing the brand equity of Universitas Muhammadiyah Tangerang include: 1) Accreditation of Institutions and Study Programs, 2) Achievements, 3) Excellent Campus Activities, 4) Premium Fees (premium price), 5) Shift Classes, and 6) Relationships with Alumni.

Second, the campus strategic steps in building brand equity in increasing campus competitiveness include: 1) Maintaining the Accreditation Value that has currently been achieved, namely being accredited by BAN-PT "B" and maintaining it on an ongoing basis, 2) Achievement, coaching students who are achieve both academic and non-academic achievements, 3) Quality graduates, conduct language course training and other extracurricular activities, and establish academic collaborations with universities in Indonesia and abroad, and 4) Alumni relations, by establishing alumni associations at the University of Muhammadiyah Tangerang and update job vacancies information to alumni.

Third, the impact of the establishment of brand equity in increasing the competitiveness of the University of Muhammadiyah Tangerang, namely: 1) The quality of service for lecturers and employees is getting better, 2) The interest of prospective students to study at the University of Muhammadiyah Tangerang increases, 3) High trust from the community towards the University campus Muhammadiyah Tangerang, and 4) Scholarship offers abroad.

\section{Acknowlegment}

The researcher would like to thank the Head of the Informatics Study Program, colleagues at the Informatics Study Program at the University of Muhammadiyah Tangerang and all parties involved in this research. Hopefully this research can contribute to the theory of communication science

\section{REFERENCES}

Armanu Thoyib. (2005). Hubungan Kepemimpinan, Budaya, Strategi, dan Kinerja: Pendekatan Konsep. Jurnal. Staf Pengajar Fakultas Ekonomi Universitas Brawijaya Malang.

Campbell, M. C. (2002). Building Brand Equity. International Journal of Medical Marketing, XXIII.

Cutlip, Scott M, Allen H, Center. Broom, Gleen M. (2006). Effective Public Relations Edisi 8. Jakarta: PT Indeks Kelompok Gramedia.

Durinto, Darmadi. Sugiarto. Tony Sitinjak. (2004). Strategi Menaklukan Pasar Melalui Riset Ekuitas dan Perilaku Merek. Jakarta: PT Gramedia Pustaka Utama.

Dedy N. Hidayat. (2003). Paradigma dan Metedologi Penelitian Sosial Empirik Klasik. Jakarta: Departemen Ilmu Komunikasi UI.

E. Kristi Poerwandari,(2007). Pendekatan Kualitatif Untuk Penelitian Perilaku Manusia. Depok: LPSP.

Hardiansyah. (2011). Kualitas Pelayanan Publik: Konsep, Dimensi, Indikator dan Implementasinya. Yoogyakarta: Gava Media

Kotler, Philip. (2005). Manajemen Pemasaran, Jilid 1 dan 2. Jakarta. PT. Indeks Kelompok Gramedia.

Kotler, P., \& Keller, K. L. (2006). Marketing Management (Vol 12th ed). New Jersey. Pearson Prentice Hall.

Kotler, Philip and Kevin Lane Keller. (2009). Manajemen Pemasaran Jilid 1,Edisi Ketiga 
Belas, Terjemahan Bob Sabran. Jakarta: Penerbit Erlangga.

Kotler, Philip and Karen F.A. Fox.(1995). Strategic Marketing for Educational Institution $2^{\text {nd }}$ Edition. Prentice Hall, Inc. New Jersey.

Lau, G. T., \& Lee. (1999). Customers Trus ina Brnad and the Link to Brand Loyalty. Journal of Market Focused Management, IV.

Michael Queen Patton.(2002). Quaitatif Research \& Evaluation Methode. California: Sage Publication.

Raco J.R.(2010). Metode Penelitian Kualitatif, Jenis, Karakteristik dan Keunggulannya. Jakarta: Grasindo.

Rangkuti Freddy.(2008).The Power of Brand. Cetakan Ketiga. Jakarta: Gramedia Pustaka Utama.

Sugiyono. (2012). Memahami Penelitian Kualitatif. Bandung: Alfabeta.

Sulaeman.A.Goziyah. 2018 .Metodologi Penelitian Bahasa dan Sastra: Jakarta : Edu Pustaka.

Knapp, D. E. (2001). The Brand Mindset.Yogyakarta: Penerbit Andi. 